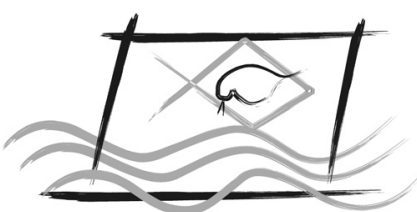

ECOTOX - BRASIL

\title{
Motionless of snail Hydrobia ulvae (Pennant) as response to sediment toxicity and its consequences for the post-exposure feeding
}

\author{
Cristiano V.M. Araújo ${ }^{1,2}$; Julián Blasco² \& Ignacio Moreno-Garrido² \\ ${ }^{1}$ IMAR-Instituto do Mar, Department of Life Sciences, University of Coimbra, Apartado 3046, 3001-401 Coimbra, Portugal \\ ${ }^{2}$ Instituto de Ciencias Marinas de Andalucía (CSIC), Campus Universitario Río San Pedro s/n, 11510, Puerto Real, Cádiz, Spain
}

(Received June 14, 2013; Accept August 11, 2013)

\begin{abstract}
Post-exposure feeding and motionless may be useful endpoints for assessing toxicity. The present study aimed to examine (i) the immobility of the estuarine snail Hydrobia ulvae resulting from short-term exposure to copper-spiked sediment, and subsequently, (ii) the potential application of post-exposure feeding (indirectly measured as pellets excreted) as an ecotoxicological response associated with motionlessness. Mobility and post-exposure feeding were influenced by copper contamination. Motionless was noticeable above the concentration of $200 \mu \mathrm{g} \mathrm{Cu} \mathrm{g}^{-1}$, where $40 \%$ of the organisms were inactive. Practically all the organisms remained active at the two lowest concentrations: 40 (control) and $60 \mu \mathrm{g} \mathrm{Cu} \mathrm{g}^{-1}$. For 400 and $800 \mu \mathrm{g} \mathrm{Cu} \mathrm{g}^{-1}$ the motionless was generally higher than 50\%. Mortality higher than $25 \%$ was observed at 200, 400 and 800 $\mu \mathrm{g} \mathrm{Cu} \mathrm{g}^{-1}$, with values of 27,40 and $60 \%$, respectively. The feeding inhibition values showed an increasing inhibition from $20 \%$ at the lowest concentration ( $\left.60 \mu \mathrm{g} \mathrm{Cu} \mathrm{g}^{-1}\right)$, up to $59 \%$ at $400 \mu \mathrm{g} \mathrm{Cu} \mathrm{g}^{-1}$; at concentration of $800 \mu \mathrm{g} \mathrm{Cu} \mathrm{g}^{-1}$, although the physical activity inhibition had reached $67 \%$, the post-exposure feeding was 1.5 higher in relation to the control. Probably, the starvation period due to motionless during exposure seems to increase the post-exposure feeding and egestion when food was provided; alternatively, increased pellet production could also indicate a detoxification process.
\end{abstract}

Keywords: copper contamination; physical activity; post-exposure feeding; spiked sediment

\section{INTRODUCTION}

Hydrobia ulvae (Pennant) (Gastropoda) is an estuarine benthic mudsnail found in intertidal ecosystems considered an important energy source for many organisms (Lillebø et al., 1999; Pascual \& Drake, 2008). Unfortunately, environmental changes and contamination, frequent in estuarine and coastal environments (Redondo-Gómez et al., 2009; Fathallah et al., 2012), threaten seriously H. ulvae populations (Lillebø et al., 1999). Because mudsnails live in direct contact with sediment (Haubois et al., 2005), they have been used to provide reliable information about the effects of sediment toxicity (Shipp \& Grant, 2006; Hampel et al., 2009; Mauffret et al., 2010; Araújo et al., 2012; Campana et al., 2013). In those studies, focused on different endpoints, such as survival, growth, feeding/egestion rate, total number of veligers or larvae produced, bioaccumulation, avoidance, and other types of behaviour, the organism showed a good discrimination capacity among sediment with different toxicity levels. For H. ulvae, physical activity (mobility) and post-exposure feeding are likely suitable measurements for assessing contaminant exposure (Hampel et al., 2009; Krell et al., 2011; Araújo et al., 2012). Mobility is a sub-lethal response that is considered highly relevant based on the assumption that motionless can lead to death (McWilliam \& Baird, 2002). In particular, physical activity has been used as the endpoint in studies with a variety of different species (such as amphipods, cladocerans, snails, and tadpoles) and

*Corresponding author: Cristiano V. M. Araújo; e-mail: cristiano.araujo@icman.csic.es 
contaminants (e.g., cadmium, fluoride ion, phenol, zinc, and acid mine drainage effluent) (Brent \& Herricks, 1998; MacedoSousa et al., 2007; Alonso \& Camargo, 2012; Denoël et al., 2013). Hampel et al. (2009) and Araújo et al. (2012) observed a reduction in the mobility of $H$. ulvae with consequent retraction into its shell in order to avoid contact with LAS (linear alkylbenzene sulphonate) and naturally contaminated sediment samples, respectively. Campana et al. (2013) showed that exposure to metal-spiked sediments altered the behaviour of snails (e.g., burying, floating, crawling and sinking). Postexposure feeding has also been considered a sensitive endpoint for assessing environmental contamination (Maltby etal., 2002; McWilliam \& Baird, 2002). Basically, post-exposure feeding assays consist of a period of exposure to the contaminant, followed by an incubation period in clean medium, where the rate of feeding is measured (McWilliam \& Baird, 2002). It is assumed that the impact on the organism during exposure will persist after the exposure has ended, and this will be reflected in post-exposure feeding. Exposure to different contaminants (e.g., carbendazim, chlorpyrifos, copper, dimethoate, naturally contaminated sediment, profenofos, pulp mill effluent, and zinc) demonstrated to affect the post-exposure feeding of the prawn Macrobrachium rosenbergii (Satapornvanit et al., 2009), the midge Chironomus riparius (Soares et al., 2005), the amphipod Echinogammarus meridionalis (Agostinho et al., 2012), the crab Carcinus maenas (Moreira et al., 2006), the polychaete Hediste (Nereis) diversicolor (Moreira et al., 2005), and the cladoceran Daphnia magna (McWilliam \& Baird, 2002; Rosa et al., 2010). Recently, Krell et al. (2011) also showed that contamination affect the post-exposure feeding of the snail $H$. ulvae.

Based on the hypothesis that the motionless, or even merely reduced physical activity, could have important implications on feeding, and that periods of starvation can also change feeding pattern of the organisms (McMahon \& Rigler, 1965; Calow, 1975), the objectives of the present study are to examine (i) physical activity of the snail $H$. ulvae resulting from exposure to different copper-spiked estuarine sediment, and (ii) the potential application of post-exposure feeding as an ecotoxicological response associated with motionlessness. Spiked sediment was used because it guarantees organisms are exposed to sediment with similar geochemistry characteristics and therefore misleading in interpretation of the toxicity response by using different sediment samples are prevented (Hutchins et al., 2009). Copper was chosen as pollutant model because it is highly toxic to H. ulvae (Campana, 2006).

\section{MATERIAL AND METHODS}

\section{Sediment: sampling, treatment and characterisation}

Sediment sample (top $0.5 \mathrm{~cm}$ ) with no toxic effect (Araújo et al., 2012) collected in a clear zone at the Guadalquivir estuary (SW Spain) was used at the spiking matrix. Sediment was mixed, placed in plastic flasks and maintained at $4{ }^{\circ} \mathrm{C}$ until processing (4 days after sampling). In order to eliminate the autochthonous biota, in the laboratory, sediment was placed in a plastic tray, forming a fine layer of sediment, on which liquid nitrogen $\left(-196{ }^{\circ} \mathrm{C}\right)$ was poured (Araújo et al., 2009). After evaporation of the liquid nitrogen and thawing, the sediment was spiked. Sediment was not sieved. Physicalchemical characterization of the sediment and background metal concentration values are provided in Table 1. Values of $\mathrm{pH}$ and redox potential (Eh) were measured $(\mathrm{pH}$ Meter 330 WTW) directly in sediment; organic matter (OM, in \%) was determined after calcination (at $450{ }^{\circ} \mathrm{C}$ for $48 \mathrm{~h}$ ); grain size (silt-clay: $<0.063 \mathrm{~mm}$ ) was determined by wet sieving; and for the determination of total organic carbon (TOC, in \%) the technique described by El-Rayis (1985) was used. Sediment subsamples (grain size $<0.063 \mathrm{~mm}$ ) were freezedried and digested in a microwave oven (CEM Corporation; Microwave Accelerated Reaction System 5) in order to analyze concentrations (in $\mu \mathrm{g} \mathrm{g}^{-1}$ dry weight) of most important metals usually found in the sediment of the Bay of Cádiz (Araújo et al., 2010), following the procedure described by Loring \& Rantala (1992). Concentrations of $\mathrm{Al}, \mathrm{Co}, \mathrm{Cr}, \mathrm{Cu}, \mathrm{Fe}, \mathrm{Li}, \mathrm{Mn}$, $\mathrm{Ni}$, and $\mathrm{Zn}$ were determined by inductively-coupled plasmaoptical emission spectrometry (ICP-OES, Perkin Elmer Optima 2000 DV); As, Cd, Pb, and Sn concentrations were determined by inductive-coupled plasma mass spectrometry (ICP-MS, Thermo, Serie X7). Reference material analysis (Community Bureau of Reference 277 and Marine Estuarine Standard Sediment-1, National Research Council of Canada) showed the accuracy of the method was higher than $83 \%$.

\section{Spiking of the sediment}

After collection and processing as described, sediment was spiked (Simpson et al., 2004) with copper as copper sulphate $\left(\mathrm{CuSO}_{4} \cdot 5 \mathrm{H}_{2} \mathrm{O}\right.$, Merck, $99 \%$ purity). Glassware used for spiking

Table 1 - Physical-chemical characterization of the sediment sample (total metal concentration are given in $\left.\mu \mathrm{g} \mathrm{g}^{-1}\right)$.

\begin{tabular}{lc}
\hline Parameters & Values \\
\hline $\mathrm{pH}$ & 7.06 \\
$\mathrm{Eh}(\mathrm{mV})$ & -27 \\
$\mathrm{OM}(\%)$ & 5 \\
$\mathrm{TOC}(\%)$ & 1 \\
$\mathrm{Grain}$ size $(\%>0.63 \mu \mathrm{m})$ & 91 \\
$\mathrm{Al}$ & 83125 \\
$\mathrm{As}$ & 17 \\
$\mathrm{Cd}$ & 0.4 \\
$\mathrm{Co}$ & 15 \\
$\mathrm{Cr}$ & 87 \\
$\mathrm{Cu}$ & 40 \\
$\mathrm{Fe}$ & 37500 \\
$\mathrm{Li}$ & 41 \\
$\mathrm{Mn}$ & 750 \\
$\mathrm{Ni}$ & 35 \\
$\mathrm{~Pb}$ & 35 \\
$\mathrm{Sn}$ & 3 \\
$\mathrm{Zn}$ & 106 \\
\hline
\end{tabular}


was cleaned with nitric acid at $10 \%$ and rinsed several times with Milli-Q ultrapure water. Copper solutions were prepared in artificial seawater (ASTM, 1975) with $\mathrm{pH}$ of 8.2, salinity 35 and dissolved oxygen (OD) concentration lower than 0.3 $\mathrm{mg} \mathrm{L}^{-1}$. In order to reach this value of $\mathrm{OD}$, the solutions were purged with nitrogen gas for $5 \mathrm{~h}$ in order to reduce the oxygen concentration and, consequently, bacteria activity. Seawater solution and sediment, in a 1:1 ratio ( $25 \mathrm{~g}$ sediment and 25 $\mathrm{mL}$ sea-water), were mixed in plastic $50 \mathrm{~mL}$ centrifuge tubes. Immediately, the tube was purged with nitrogen gas for 30 $\mathrm{s}$ before closing. Then, the tube contents were homogenized using a Rotabit orbital stirrer (Selecta) for $48 \mathrm{~h}$, at $150 \mathrm{rpm}$. Spiked sediment was stored at $20^{\circ} \mathrm{C}$, in darkness, for 15 days. On the $7^{\text {th }}$ day all the tubes were purged with nitrogen gas again for $60 \mathrm{~s}$. After 15 days the tubes were centrifuged at $2700 \mathrm{~g}$ for $5 \mathrm{~min}$ before the tests, in order to eliminate interstitial water. Nominal values for final copper concentrations in the batches of sediment assayed were: $60,120,200,400$ and $800 \mu \mathrm{g} \mathrm{g}^{-1}$ plus non-spiked reference sediment $\left(40 \mu \mathrm{g} \mathrm{g}^{-1}\right)$, hereafter named control. Exposure concentrations chosen were based on a previous study developed by Campana (2006).

\section{H. ulvae individuals}

Adult individuals ( $>3 \mathrm{~mm}$ length) of the snail H. ulvae were collected by hand picking and in a shallow coastal lagoon considered unpolluted from the Bay of Cadiz (SW Spain), where snails' populations has been monitored for long years (Drake \& Arias, 1995; Pascual \& Drake, 2008). The culture was maintained for three weeks in aquaria containing $2 \mathrm{~L}$ of filtered seawater $(0.7 \mu \mathrm{m}$ pore size filter $)$, collected from the Bay of Cádiz, which was renewed weekly. Temperature (20 $\left.\pm 2{ }^{\circ} \mathrm{C}\right)$, salinity $(33 \pm 2)$, and photoperiod $(16 / 8 \mathrm{~h} \mathrm{light} /$ dark $)$ were monitored. Organisms were fed with aliquots ad libitum of lyophilized Ulva sp. Mortality during the acclimatization period was less than $10 \%$. Twenty four hours before the assays, organisms were starved in order to stimulate them to forage (i.e. to increase their potential mobility). During this starvation period, water was renewed three times in order to prevent coprophagia (feeding on produced pellets).

\section{Effects on physical activity}

Spiked and control sediment $(0.5 \mathrm{~g})$ were spread evenly in plastic Petri dishes $\left(23.8 \mathrm{~cm}^{2}\right)$ by triplicate. A volume of $8 \mathrm{~mL}$ of artificial seawater was added to dishes, vigorously mixed with the sediment and then allowed to settle and equilibrate during $24 \mathrm{~h}$. A shallow layer of water was formed above the sediment, but not sufficient to permit floating activity. On the inner sides of the dishes, sheets of sandpaper were attached with non-toxic silicone, in order to ensure that snails could not climb out, ensuring thus constant contact with sediment. Five organisms were randomly distributed in dishes containing a copper treated sediment sample each. All dishes were nonhermetically closed and incubated under the same conditions of culture. After 24, 48, 72 and $96 \mathrm{~h}$ the immobility of each organism was recorded. To assess snail immobility, each replicate was individually submitted to stereomicroscopy with continuous light and during a ten minute period, and each organism was checked for movement. An organism that presented crawling activity or moving into or out of its shell was considered active. All measurements were always carried out at 10:00 am in order to avoid behavioural changes due to differences in the observation hour (potential circadian cycles of activity/inactivity).

\section{Effects on post-exposure feeding}

After the last measurement of mobility, organisms were placed individually in one well of a microplate (12-wells suspension culture-plates, 17.8/16 MM and 127.8/85/19 MM CELLSTAR, Greiner Bio-One) containing $5 \mathrm{~mL}$ of clean artificial sea-water, without sediment, and $2 \mathrm{mg}$ of lyophilized Ulva sp. provided as food. Organisms were maintained in these wells for $3 \mathrm{~h}$ and, during this period, the presence or absence of movement in individuals determined as non-active in the previous test was verified. It was expected that food supply would stimulate any non-active organism to feed and display movement; therefore any organism that remained inactive during that period was considered dead. No mortality was registered in control treatment. After recording incidence of mortality (after $3 \mathrm{~h}$ ), snails were kept in the same wells containing $5 \mathrm{~mL}$ artificial seawater, without sediment and with food, for postexposure feeding test for $24 \mathrm{~h}$. In this phase, feeding rate was measured indirectly by number of produced faecal pellets; this is considered a good indirect measure of snail feeding (Shipp \& Grant, 2006). After $24 \mathrm{~h}$ feeding, snails were transferred to wells with clean water and without food and sediment where the pellets were counted for $3 \mathrm{~h}$. In this time period, $80 \%$ of total pellets are produced (Pascual \& Drake, 2008). Every 30 min all the pellets produced were removed in order to prevent coprophagia and erosion of the pellets.

\section{Statistical analysis}

Active individuals (\%) were calculated from the total number (15) of snails exposed for treatment. Mobility was based on organism total number in order to reduce the importance of each organism in the analysis, as 5 organisms were introduced by replicate. Most important information about physical activity response was to verify that in increasing concentrations there were more inactive individuals and so more individuals in starvation. However, faecal pellet production was determined on an individual basis. For calculating the percentage reduction in feeding, the number of pellets produced by organisms exposed to control sediment was taken as reference $(100 \%)$. Statistical difference in pellet production was checked using Anova and Tukey's post-hoc test $(p<0.05)$.

\section{RESULTS}

There was no mortality in the control treatment after 96 $\mathrm{h}$ exposure. Physical activity of snails recorded at short- 
term (throughout the $96 \mathrm{~h}$ ) of exposure to the copper-spiked sediment decreased with increasing concentration (Fig. 1). This effect was pronounced above the concentration of $200 \mu \mathrm{g} \mathrm{Cu} \mathrm{g}^{-1}$, where $40 \%$ of the organisms were inactive. Practically all the organisms remained active at the two lowest concentrations: 40 (control) and $60 \mu \mathrm{g} \mathrm{Cu} \mathrm{g}^{-1}$. For 400 and 800 $\mu \mathrm{g} \mathrm{Cu} \mathrm{g}^{-1}$ the motionless at 24, 48, 72 and $96 \mathrm{~h}$ were generally higher than $50 \%$. Results clearly showed that mobility was inhibited throughout the assay as a function of the input of copper and that the motionless recorded at the end of the assay was similar to that at the beginning.

Because mortality is difficult to measure in snails (dead individuals can be confused with inactive individuals), it was recorded after stimulation for $3 \mathrm{~h}$ with food, as previously described. Individuals that remained inactive were considered dead. Mobility was recovered after this stimulation in two organisms classified as inactive at a concentration of $60 \mu \mathrm{g}$ $\mathrm{Cu} \mathrm{g}^{-1}$; in one organism at $400 \mu \mathrm{g} \mathrm{Cu} \mathrm{g}^{-1}$; and in one at $800 \mu \mathrm{g}$ $\mathrm{Cu} \mathrm{g}^{-1}$. Mortality found to be higher than $25 \%$ were observed at concentrations of 200,400 and $800 \mu \mathrm{g} \mathrm{Cu} \mathrm{g}^{-1}$, with values of 27,40 and $60 \%$, respectively.

The number of faecal pellets counted for each organism and treatment after feeding is plotted in Fig. 2. When exposed to control sediment, 16 pellets per individual were produced. At increasing concentrations (up to $400 \mu \mathrm{g} \mathrm{Cu} \mathrm{g}^{-1}$ ) the egestion decreased as a function of the input of copper; however, at 800 $\mu \mathrm{g} \mathrm{Cu} \mathrm{g}^{-1}$, production of pellets was high, around 24 pellets per individual. Mean numbers of pellets $( \pm \mathrm{SD})$ produced by individuals for each concentration (control, 60, 120, 200, 400, and $\left.800 \mu \mathrm{g} \mathrm{Cu} \mathrm{g}^{-1}\right)$ were $16( \pm 6), 12.5( \pm 9), 11.7( \pm 5), 8.7$ $( \pm 5), 6.4( \pm 2)$, and $24.2( \pm 13)$ respectively, with statistically difference $\left(p<0.05 ; F_{5,42}=3.593\right)$ between $800 \mu \mathrm{g} \mathrm{Cu} \mathrm{g}^{-1}$ and the concentrations 200 and $400 \mu \mathrm{g} \mathrm{Cu} \mathrm{g}^{-1}$. Based on the egestion shown by organisms exposed to control sediment, the feeding inhibition values for each concentration showed an increasing

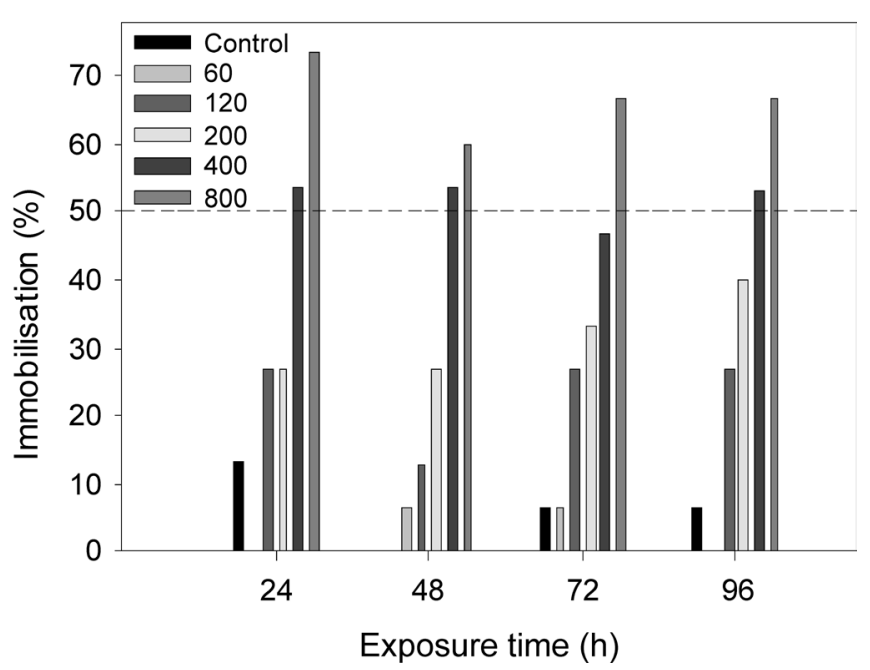

Fig. 1 - Percentage of immobile individuals of snail Hydrobia ulvae exposed to copper-spiked sediment during $96 \mathrm{~h}$. The dashed line indicates $50 \%$ effect. Nominal copper concentrations (top left) are expressed in $\mu \mathrm{g} \mathrm{g}^{-1}$. Data where bar is missed indicate $0 \%$ of immobilisation.

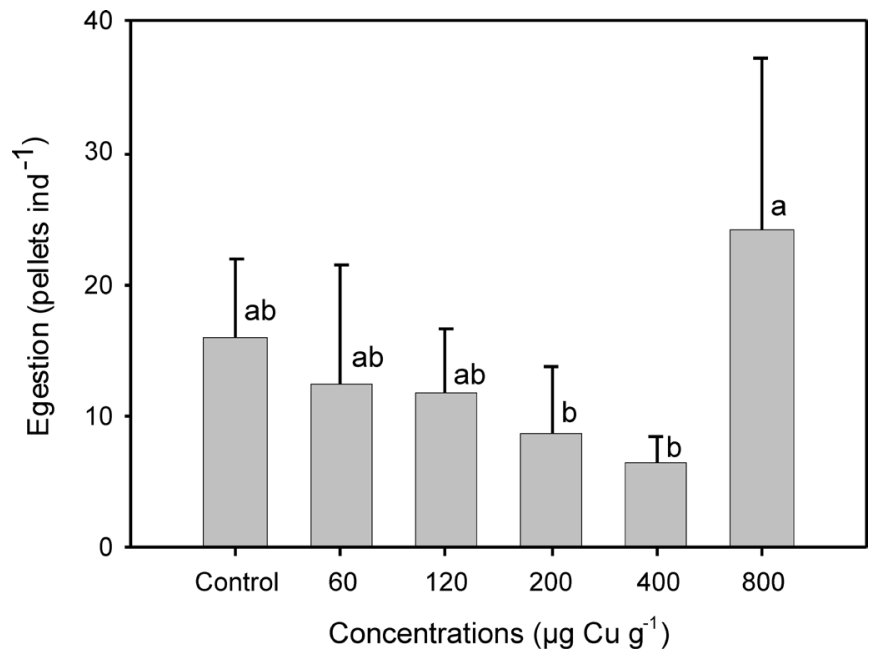

Fig. 2 - Mean egestion/excretion ( $n^{\circ}$. of pellets per organism) of snail Hydrobia ulvae after exposure to copper-spiked sediment. Different letters indicate statistically $(p<0.05)$ different means.

inhibition from $20 \%$ at the lowest concentration, up to $59 \%$ at $400 \mu \mathrm{g} \mathrm{Cu} \mathrm{g}^{-1}$; but this response decreased to a negative value $(-53 \%)$ when organisms had previously been exposed at 800 $\mu \mathrm{g} \mathrm{Cu} \mathrm{g}^{-1}$.

\section{DISCUSSION}

Physical activity is an endpoint able to discriminate between different inputs of copper in sediment. The sensitivity of motionless as an endpoint has also been reported in other studies with H. ulvae (Hampel et al., 2009; Araújo et al., 2012; Campana et al., 2013). Observed effects of copper at short-term exposure on snails' physical activity in this study are in accordance with results described by Campana (2006), who observed that, at concentrations of 0,50 and $100 \mu \mathrm{g} \mathrm{Cu}$ $\mathrm{g}^{-1}$ in spiked sediment, the activity of $H$. ulvae was similar to that when exposed to the control sediment, with organisms presenting three main activities: floating, burrowing and crawling; in contrast, at 200 and $400 \mu \mathrm{g} \mathrm{Cu} \mathrm{g}^{-1}$ those activities were reduced and mortality began to occur. Post-exposure feeding, determined by pellets production, also demonstrated to be a response capable of discriminating among different sediment copper toxicity levels, after previous short-term exposure to copper. According Krell et al. (2011) postexposure feeding was found to be three times more sensitive than lethality, but less sensitive than growth, when H. ulvae was exposed to copper in water.

Results of post-exposure feeding obtained in the highest concentration tested were unusual, and they indicate that information obtained by using this endpoint must be treated with caution. In sediment with the highest copper concentration, the number of pellets produced was 1.5 times greater than in the control sediment. This result could be associated with the longer $24 \mathrm{~h}$ post-exposure feeding period employed. Since other authors have recommended a very short post-exposure feeding period (sometimes $<1 \mathrm{~h}$ ) in order to minimize any possible physiological recovery by the organism from the 
effects of toxicants suffered during exposure (Krell et al., 2011), in our study a shorter post-exposure feeding period of $3 \mathrm{~h}$ rather than $24 \mathrm{~h}$ was initially used, and the number of pellets produced by organisms exposed to the most contaminated sediment was still 1.3 times greater than pellets produced in control sediment (data not shown). This indicates that shorter post-exposure feeding period had little influence on the results.

In studies in which post-exposure feeding is used to assess previous exposure, no food is provided, in order to avoid interference in the results. When post-exposure feeding is used to assess previous exposure to sediment, detritus, microalgae and bacteria associated with the sediment could be used as a food source during the exposure. The higher post-exposure feeding observed at the highest concentration could likely be linked to the response of a major reduction in physical activity. Individuals exposed to most contaminated sediment did not feed during the test due to motionless; in contrast, individuals exposed to lower concentrations were more active and were able to feed, albeit suffering the effects of contamination, what was recorded in subsequent feeding conditions. Once the exposure was ended and food was provided, possibly those organisms exposed to the most contaminated sediment increased their feeding to compensate for the period in starvation. Calow (1975) showed that, when food was available after varying periods of starvation, the ingestion rate for two freshwater gastropods, as well as the absorption efficiency, increased. It was demonstrated that Daphnia magna submitted to a starvation period, when they were exposed to non-limiting food concentration after starvation, ingested food more rapidly than the animals that had been fed (McMahon \& Rigler, 1965). These authors indicated that inhibitory or toxic foods should also decrease food intake in a similar way to imposed starvation. On the other hand, the higher egestion obtained at the highest concentrations could also be a mechanism of detoxification caused by the ingestion of toxic material with consequent egestion of this material and mucus associated. An increased external mucus production has been described for H. ulvae when exposed to different contaminants like LAS, copper, cadmium, zinc (Hampel et al., 2009; Campana et al., 2013) and the role of the mucus in preventing the assimilation of aluminum has also been evidenced (Balance et al., 2002). Therefore, given that gastropods produce mucus within their guts (Davies \& Hawkins, 1998), and that after the starvation the activity and secretion of digestive juices could increase (Calow, 1975), the increase of toxicity might have generated a high level of mucus being secreted to generate a barrier and limit direct exposure (Brooks \& White, 1995; Desouky, 2006). At the end of the acute exposure, the mucus, granules and toxic material would then be excreted by fecal pellets (Brooks \& White, 1995; Desouky, 2006). Therefore, we could hypothesize that snails exposed to highly contaminated sediment could excrete higher quantity of pellets. To test this hypothesis it would be necessary to examine the composition of the pellets regarding constitutive material and presence of copper. This would be studied in further researches.
Post-exposure feeding of $H$. ulvae demonstrated to be a sensitive and reliable endpoint for toxicity assessment. However, it needs to be analysed with caution in wholesediment toxicity tests because interference can exist due to food availability present in sediments. In this sense, two factors should be taken into account: (i) snails are able to alter the ingestion (Haubois et al., 2005) and (ii) particularly H. ulvae can adopt different feeding strategies as a function of the sediment contamination levels (Granberg \& Forbes, 2006). In addition, if motionless is observed during exposure to avoid continuous exposure to contaminants, probably the organisms will be in starvation and the measurements of the post-exposure feeding could be misinterpreted by a further increasing in ingestion.

\section{ACKNOWLEDGMENTS}

CVM Araújo is grateful to the FCT-Portugal (Fundação para a Ciência e a Tecnologia) for his postdoctoral fellowship (reference SFRH/BPD/74044/2010). The authors also thank José María Espigares, Lourdes Bordonado, María del Carmen Agulló Cornejo, Araceli Rodríguez and Pilar Drake for their contributions.

\section{REFERENCES}

AGOSTINHO, M., MOREIRA-SANTOS, M. \& RIBEIRO, R., 2012. A freshwater amphipod toxicity test based on postexposure feeding and the population consumption inhibitory concentration. Chemosphere, 87: 43-48. http://dx.doi.org/10.1016/j. chemosphere.2011.11.052

ALONSO, A. \& CAMARGO, J.A., 2012. A video-based tracking analysis to assess the chronic toxic effects of fluoride ion on the aquatic snail Potamopyrgus antipodarum (Hydrobiid, Mollusca). Ecotoxicol. Environ. Saf., 81: 70-75. http://dx.doi.org/10.1016/j. ecoenv.2012.04.019

ARAÚJO, C.V.M., DIZ, F.R., LAIZ, I., LUBIÁN, L.M., BLASCO, J. \& MORENO-GARRIDO, I., 2009. Sediment integrative assessment of the Bay of Cádiz (Spain): an ecotoxicology and chemical approach. Environ. Int., 35: 831-841. http://dx.doi. org/10.1016/j.envint.2009.02.003

ARAÚJO, C.V.M., DIZ, F.R., TOERNERO, V., LUBIÁN, L.M., BLASCO, J. \& MORENO-GARRIDO, I., 2009. Ranking sediment samples from three Spanish estuaries in relation to its toxicity for two benthic species: the microalgae Cylindrotheca closterium and the copepod Tisbe battagliai. Environ. Toxicol. Chem., 29: 393-400. http://onlinelibrary.wiley.com/doi/10.1002/ etc. $46 / \mathrm{pdf}$

ARAÚJO, C.V.M., BLASCO, J. \& MORENO-GARRIDO, I., 2012. Measuring the avoidance behaviour shown by snail Hydrobia ulvae exposed to sediment with a known contamination gradient. Ecotoxicology, 21: 750-758. http://link.springer.com/article/10.1 007\%2Fs10646-011-0835-6

ASTM-American Standard for Testing and Materials. 1975. Standard Specification for Substitute Ocean Water. Designation D 114175.

BALLANCE, S., SHEEHAN, J.K., TKACHENKO, A., MCCROHAN, C.R. \& WHITE, K.N., 2002. Interaction of mucus with freshly neutralised aluminium in freshwater. J. Inorg. Biochem., 92: 11-18. http://dx.doi.org/10.1016/S01620134(02)00474-9 
BRENT, R.N. \& HERRICKS, E.E., 1998. Postexposure effects of brief cadmium, zinc, and phenol exposures on freshwater organisms. Environ. Toxicol. Chem., 17(10): 2091-2099. http:// onlinelibrary.wiley.com/doi/10.1002/etc.5620171027/pdf

BROOKS, A.W. \& WHITE, K.N., 1995. The localization of aluminium in the digestive gland of the terrestrial snail Helix aspersa. Tissue Cell, 27: 61-72. http://dx.doi.org/10.1016/ S0040-8166(95)80010-7

CALOW, P., 1975. The feeding strategies of two freshwater gastropods, Ancylus fluviatilis Müll. and Planorbis contortus Linn. (Pulmonata) in terms of ingestion rates and absorption efficiencies. Oecologia, 20: 33-49. http://link.springer.com/ article/10.1007\%2FBF00364320

CAMPANA, O., 2006. Evaluación de la contaminación de metales en los sedimentos del estuario del Río Guadalete. PhD Thesis, University of Cádiz.

CAMPANA, O., RODRÍGUEZ, A. \& BLASCO, J., 2013. Evaluating the suitability of Hydrobia ulvae as a test species for sediment metal toxicity testing applying a tissue residue approach to metal mixtures in laboratory and field exposures. Chemosphere, 91: 1136-1145. http://dx.doi.org/10.1016/j. chemosphere.2013.01.018

DAVIES, M.S. \& HAWKINS, J., 1998. Mucus from marine mollusks. Adv. Mar. Biol., 34: 1-71. http://dx.doi.org/10.1016/ S0065-2881(08)60210-2

DENOËL, M., LIBON, S., KESTEMONT, P., BRASSEUR, C., FOCANT, J-F. \& DE PAUW, E., 2013. Effects of a sublethal pesticide exposure on locomotor behavior: a video-tracking analysis in larval amphibians. Chemosphere, 90: 945-951. http:// dx.doi.org/10.1016/j.chemosphere.2012.06.037

DESOUKY, M.M.A., 2006. Tissue distribution and subcellular localization of trace metals in the pond snail Lymnaea stagnalis with special reference to the role of lysosomal granules in metal sequestration. Aquat. Toxicol., 77: 143-152. http://dx.doi. org/10.1016/j.aquatox.2005.11.009

DRAKE, P. \& ARIAS, A., 1995. Distribution and production of three Hydrobia species (Gastropoda: Hydrobiidae) in a shallow coastal lagoon in the Bay of Cádiz, Spain. J. Moll. Stud., 61: 185196. Doi: 10.1093/mollus/61.2.185

EL-RAYIS, O.A., 1985. Re-assessment of the titration method for determination of organic carbon in recent sediments. Rapp. Comm. Int. Mer. Médit., 29: 45-47.

FATHALLAH, S., MEDHIOUB, M.N., MEDHIOUB, A. \& KRAIEN, M.M., 2012. Sediment toxicity bioassays using Ruditapes decussatus embryos and larvae to assess the contamination in four sites on the coast of Tunisia. Soil Sed. Contam., 21: 351363. http:// doi/pdf/10.1080/15320383.2012.664182

GRANBERG, M.E. \& FORBES, T.L., 2006. Role of sediment organic matter quality and feeding history in dietary absorption and accumulation of pyrene in the mud snail (Hydrobia ulvae). Environ. Toxicol. Chem., 25: 995-1006. http://onlinelibrary. wiley.com/doi/10.1897/05-140R.1/pdf

HAMPEL, M., MORENO-GARRIDO, I., GONZÁLEZ-MAZO, E. \& BLASCO, J., 2009. Suitability of the marine prosobranch snail Hydrobia ulvae for sediment toxicity assessment: a case study with the anionic surfactant linear alkylbenzene sulphonate (LAS). Ecotoxicol. Environ. Saf., 72: 1303-1308. http://dx.doi. org/10.1016/j.ecoenv.2008.09.005

HAUBOIS, A.G., GUARINI, J.M., RICHARD, P., FICHET, D., RADENAC, G. \& BLANCHARD, G.F., 2005. Ingestion rate of the deposit-feeder Hydrobia ulvae (Gastropod) on epipelic diatoms: effect of cell size and algal biomass. J. Exp. Mar. Biol. Ecol., 317: 1-12. http://dx.doi.org/10.1016/j.jembe.2004.11.009
HUTCHINSON, C.M., TEASDALE, P.R., LEE, S.Y. \& SIMPSON, S.L., 2009. The effect of sediment type and $\mathrm{pH}-$ adjustment on the porewater chemistry of copper- and zincspiked sediments. Soil Sed. Contam., 18: 55-73. http://doi/ pdf/10.1080/15320380802545407

KRELL, B., MOREIRA-SANTOS, M. \& RIBEIRO, R., 2011. An estuarine mudsnail in situ toxicity assay based on postexposure feeding. Environ. Toxicol. Chem., 30: 1935-1942. http:// onlinelibrary.wiley.com/doi/10.1002/etc.585/pdf

LILlEBØ, A.I., PARDAL, M.A. \& MARQUES, J.C., 1999. Population structure, dynamics and production of Hydrobia ulvae (Pennant) (Mollusca: Prosobranchia) along an eutrophication gradient in the Mondego estuary (Portugal). Acta Oecologica, 20: 289-304. http://dx.doi.org/10.1016/S1146-609X(99)00137-X

LORING, D.H. \& RANTALA, R.T.T., 1992. Manual for the geochemical analyses of marine sediments and suspended particulate matter. Earth Sci. Rev., 32: 235-283. http://dx.doi. org/10.1016/0012-8252(92)90001-A

MACEDO-SOUSA, J.A., PESTANA, J.L.T., GERHARDT, A., NOGUEIRA, A.J.A. \& SOARES, A.M.V.M., 2007. Behavioural and feeding responses of Echinogammarus meridionalis (Crustacea: Amphipoda) to acid mine drainage. Chemosphere, 67: 1663-1670. http://dx.doi.org/10.1016/j. chemosphere.2006.11.055

MALTBY, L., CLAYTON, S.A., WOOD, R.M. \& MCLOUGHLIN, N., 2002. Evaluation of the Gammarus pulex in situ feeding assay as a biomonitor of water quality: robustness, responsiveness, and relevance. Environ. Toxicol. Chem., 21: 361-368. http:// onlinelibrary.wiley.com/doi/10.1002/etc.5620210219/pdf

MAUFFRET, A., RICO-RICO, A., TEMARA, A. \& BLASCO, J., 2010. Exposure of the marine deposit feeder Hydrobia ulvae to sediment associated LAS. Environ. Pollut., 158: 529-535. http:// dx.doi.org/10.1016/j.envpol.2009.08.013

MCMAHON, J.W. \& RIGLER, F.H., 1965. Feeding rate of Daphnia magna Strauss in different foods labeled with radioactive phosphorus. Limnol. Oceanogr., 10: 105-113. http://www. aslo.org/lo/toc/vol_10/issue_1/0105.html. Doi:10.4319/ lo.1965.10.1.0105

MCWILLIAM, R.A. \& BAIRD, D.J., 2002. Postexposure feeding depression: a new toxicity endpoint for use in laboratory studies with Dapnhia magna. Environ. Toxicol. Chem., 21: 1198- 1205. http://onlinelibrary.wiley.com/doi/10.1002/etc.5620210718/pdf

MOREIRA, S.M., MOREIRA-SANTOS, M., GUILHERMINO, L. \& RIBEIRO, R., 2005. A short-term sublethal in situ toxicity assay with Hediste diversicolor (Polychaeta) for estuarine sediments based on postexposure feeding. Environ. Toxicol. Chem., 24: 2010-2018. http://onlinelibrary.wiley.com/doi/10.1897/04473R1.1/pdf

MOREIRA, S.M., MOREIRA-SANTOS, M., GUILHERMINO, L. \& RIBEIRO, R., 2006. An in situ postexposure feeding assay with Carcinus maenas for estuarine sediments-overlying water toxicity evaluations. Environ. Pollut., 139: 318-329. http:// dx.doi.org/10.1016/j.envpol.2005.05.004

PASCUAL, E. \& DRAKE, P., 2008. Physiological and behavioural responses of the mud snails Hydrobia glyca and Hydrobia ulvae to extreme water temperature and salinities: implications for their spatial distribution within a system of temperate lagoons. Physiol. Biochem. Zool., 81: 594-604. http://www.jstor.org/dis cover $/ 10.1086 / 588173$ ?uid=2132\&uid $=2 \&$ uid $=70 \&$ uid $=4 \&$ si $\mathrm{d}=21102813347153$. Doi: $10.1086 / 588173$.

REDONDO-GÓMEZ, S., CANTOS, M., MATEOS-NARANJO, E., ENRIQUE FIGUEROA, M. \& TRONCOSO, A., 2009. Heavy metals and trace element concentrations in intertidal soils of four 
estuaries of SW Iberian Peninsula. Soil Sed. Contam., 18: 320327. Doi:10.1080/15320380902772646

ROSA, R., MOREIRA-SANTOS, M., LOPES, I., SILVA, L., REBOLA, J., MENDONÇA, E., PICADO, A. \& RIBEIRO, R., 2010. Comparison of a test battery for assessing the toxicity of a bleachedkraft pulp mill effluent before and after secondary treatment implementation. Environ. Monit. Assess., 161: 439451. http://link.springer.com/article/10.1007\%2Fs10661-009-0 $759-2$

SATAPORNVANIT, K., BAIRD, D.J. \& LITTLE, D.C., 2009. Laboratory toxicity test and postexposure feeding inhibition using the giant freshwater prawn Macrobrachium rosenbergii. Chemosphere, 74: 1209-1215. http://dx.doi.org/10.1016/j. chemosphere.2008.11.033
SHIPP, E. \& GRANT, A., 2006. Hydrobia ulvae feeding rates: a novel way to assess sediment toxicity. Environ. Toxicol. Chem., 25: 3246-3252. http://onlinelibrary.wiley.com/doi/10.1897/06057R.1/pdf

SIMPSON, S.L., ANGEL, B.M. \& JOLLEY, D.F., 2004. Metal equilibration in laboratory-contaminated (spiked) sediments used for the development of whole-sediment toxicity tests. Chemosphere, 54: 597-609. http://dx.doi.org/10.1016/j. chemosphere.2003.08.007

SOARES, S., CATIVA, I., MOREIRA, S., ANDRADE, S., GUILHERMINO, L. \& RIBEIRO, R., 2005. Freshwatersaltwater interface and estuarine sediment in situ assay based on post-exposure feeding of chironomids and polychaetes. Estuaries, 28: 314-319. http://link.springer.com/ article/10.1007\%2FBF02732864 